\title{
0 combate à simonia na correspondência de Pedro Damiano: uma retórica reformadora do século XI?
}

Claudia Regina Bovo*

Resumo: A simonia dispõe de uma longa história de qualificação e combate nos textos cristãos. Na correspondência de Pedro Damiano, encontramos suas principais concepções eclesiológicas e as ações cabíveis para o combate desta falta que, segundo alguns historiadores partidários da tese de Augustin Fliche sobre a reforma gregoriana, era o elemento integrador de um programa de reformas encabeçado pelo papado no século XI. À luz da organização diacrônica do epistolário Damianense (1042-1072), buscamos neste artigo fazer uma revisão desses estudos, investigando os significados do combate à simonia impetrados pelo avelanita. Especificamente, interessa-nos compreender se a simonia integrava um programa de ações reformadoras incentivadas pelo papado e referendada pelos interlocutores de Pedro Damiano - como Humberto, cardeal de Silva Cândida, - ou se era uma prerrogativa de fortalecimento e institucionalização da comunidade eremítica de Fonte Avellana.

Palavras-chave: Simonia. Pedro Damiano. Reforma Gregoriana. Fonte Avellana.

\section{Introdução}

Desde o século XIX, os estudiosos dedicam-se a investigar os movimentos eclesiásticos de moralização e enrigecimento disciplinar dos séculos XI e XII e os personagens responsáveis por empreen-

\footnotetext{
* Professora do Departamento de História da Universidade Federal do Triângulo Mineiro e do Programa de Pós-Graduação em História da Universidade Federal do Mato Grosso, pesquisadora do Vivarium e do LEME - Laboratório de Estudos Medievais. E-mail:claubovo@yahoo.com.
} 
der aquilo que acreditavam ser o início do processo de centralização política da Igreja Católica. De acordo com essa tradição historiográfica, que teve na figura de Augustin Fliche um dos seus principais expoentes, após o pontificado de Leão IX (1049-1054), as diferentes gerações de papas que conduziram a Sé Romana até o século XII estariam todas empenhadas na concretização de uma agenda comum de ações moralizantes e disciplinares. Por esse viés interpretativo, monges e clérigos teriam agido sempre em nome do papado, conformando maneiras de se promover a purificação do corpo eclesial e sua liberação da tutela laica. Esse quadro explicativo contribuiu significativamente para classificar o religioso Pedro Damiano (10071072) como um integrante do partido romano, reconhecendo sua produção escrita como um embrião do movimento de reforma gregoriana.

Neste artigo, pretendemos apresentar as interpretações que Pedro Damiano formalizou sobre a simonia em sua correspondência. Produção escrita que se estendeu de 1042 a 1072, ano de sua morte. Nosso objetivo é investigar se o combate à simonia integrava um programa de ações reformadoras incentivadas pelo papado e referendada por seus interlocutores diretos na questão - especificamente, Humberto, cardeal de Silva Cândida, - ou se era uma prerrogativa de fortalecimento e institucionalização da comunidade eremítica de Fonte Avellana, na qual Pedro Damiano tinha origem.

O levantamento e a caracterização da simonia a partir de suas cartas permite que nos aproximemos de uma das contendas doutrinais mais debatidas nos séculos XI e XII (FLICHE, 1924; GILCHRIST, 1993). Além disso, a multiplicação dos discursos em torno do combate dessa falta e sua crescente regularização nos cânones conciliares determinaram as interpretações historiográficas a respeito de um projeto de reforma encabeçado pelo papado. Nesse sentido, o exame apurado dos significados da simonia na correspondência de Pedro Damiano pode nos auxiliar na compreensão das estratégias utilizadas pelos avelanitas para a afirmação de sua auctoritas junto aos pontífices romanos, mas, sobretudo, ele nos permitirá perceber a extensão ou o limite do conceito de reforma gregoriana.

\section{As expressões do Simoniacus Draco}

Anos 90, Porto Alegre, v. 20, n. 38, p. 75-101, dez. 2013 


\section{nas obras Damianenses}

A simonia dispõe de uma longa história de qualificação e combate nos textos cristãos. Esta falta tem seu nome derivado da passagem dos Atos dos Apóstolos 8.18-23 (BIBLIA SACRA VULGATA, 2006), na qual Simão Mago, ao verificar que o Espírito Santo era dado pelos apóstolos através da empostação das mãos, ofereceu-lhes dinheiro para obter deles o mesmo poder. Segundo Joseph Lynch (1976, p. 65-66), o século XI foi o período de maior polemização da simonia, no qual se adensou à questão uma profunda exegese sobre a venda de bens espirituais, com a passagem de Reis 5:16-27, a retomada de normas canônicas antigas, como o segundo cânone do Concílio de Calcedônia ${ }^{1}$, de 451, e o uso de contos apócrifos sobre Simão Mago. Mas, no geral, apesar de repetidamente condenada, a prática da simonia parecia inevitável em um meio social, cuja nomeação aos ofícios eclesiásticos garantia, muitas vezes, o controle sobre um vasto patrimônio material (GILCHRIST, 1993). Nesse sentido, durante todo o século XI, mesmo diante do fortalecimento da propaganda antissimoníaca impetrada por diversos grupos sociais e dos concílios convocados para a sua condenação ${ }^{2}$, muitos daqueles acusados dessa falta, apesar de condenados, retomavam seus postos clericais após reconhecerem seu erro e fazerem penitência.

A primeira obra de Pedro Damiano a considerar os perigos que envolviam a prática simoníaca foi a Vida de São Romualdo. Segundo Giovanni Lucchesi (1972), sua composição data da segunda metade de 1042, momento em que Damiano se encontrava no mosteiro de São Vicente, a pedido do abade desta casa, para auxiliar na correção dos monges ali enclausurados ${ }^{3}$. Historiadores de diferentes gerações e escolas historiográficas tomam a Vida de São Romualdo como uma espécie de "narrativa da orientação eremítica" de Pedro Damiano e da comunidade de Fonte Avellana (BLUM, 1947; COLIN, 1985; TABACCO, 1993). Por ser uma de suas primeiras obras, a Vita Beati Romualdi apresenta os primeiros preceitos da atividade eremítica que Pedro Damiano adotou desde 1035, inspirado pela tradição ascética de Romualdo de Ravenna. Tomada simultaneamente como uma narrativa de origem e uma orientação sobre a especificidade do eremitismo avelatina, em setenta e dois 
capítulos, essa hagiografia apresenta a opção de Romualdo de Ravenna pela vida eremítica. Vejamos:

Romualdo por não poder suportar a esterelidade de sua vida, se colocou a procurar com ávida ansiedade o lugar onde pudesse oferecer os frutos às almas. Enviou emissários aos condes da província de Camerino. Estes, ao ouvirem o nome de Romualdo, se encheram de grande alegria e lhe ofereceram tudo o que era possível em se tratando de florestas, montanhas e campos. Enfim, Romualdo encontrou sobre as terras deles um local conveniente para a vida eremítica, circundado por montes e florestas por todos os lados. [...] Eles se estabeleceram nesse local [Val de Castro]. Após ter construído as celas, o venerável homem passou a habitá-las juntamente com seus discípulos. Quem poderia descrever ou dizer sobre todas as graças que o senhor concedeu às almas através de seu intermediário? Eis que as pessoas quiseram afluir de todas as partes para fazer penitência, distribuindo misericordiosamente os seus bens aos pobres, enquanto outros abandonaram completamente o mundo e se submeteram com fervor à regra monástica. $\mathrm{O}$ santíssimo homem aparecia tal como um serafim, pois por toda a parte onde ia queimava incomparavelmente a chama do amor divino e inflamava os corações com sua santa pregação. (DAMIANO, 1844, p. 986)

Apresentando Romualdo como um predestinado à vida eremítica, Damiano enfatiza as condições simples de origem desta primeira comunidade anacorética em Val de Castro, cujo fato de estar circundada por florestas e campos garantia não só a reprodução de uma condição de vida inóspita (imitatio christi), como também assegurava a distância de ambientes populosos, sujeitos a tentações mundanas e ao desvio da obediência ascética. Porém, o elemento mais importante nessa passagem é a contínua intervenção de Romualdo no mundo através da pregação. Dessa maneira, a opção pela vida eremítica não se resumia pura e simplesmente a uma vida de abandono da sociedade, mas referia-se à manutenção do equilíbrio entre momentos de isolamento e pregação. É justamente 
nesse momento da narrativa que o combate à simonia desponta como uma prerrogativa da ação interventora do eremita no mundo. Segundo Pedro Damiano:

Ele repreendeu com tamanha severidade os clérigos seculares que tinham sido ordenados por simonia; afirmava que eles seriam condenados e se tornariam heréticos caso não abandonassem espontaneamente a ordem que eles receberam. Estes, compreendendo tal dito como inconcebível, decidiram matá-lo. Com efeito, durante todo este período até o tempo de Romualdo, o costume tinha se estabelecido tão efectivamente que era mal visto julgar como pecado a heresia da simonia. Romualdo lhes disse: 'Tragam-me os livros dos santos cânones e me provem através de vossos próprios livros se o que eu digo é verdade’! Consultando com cuidado, eles descobriram seus crimes e se lamentaram por seus erros. Eis que o santo homem editou certas regras e ensinou aos clérigos que viviam no século ao modo dos laicos à obedecer seus superiores e à viver conjuntamente em comunidade. Alguns bispos que tinham ocupado suas sés por simonia vieram até ele para fazer penitência. Se reportando ao venerável homem, eles prometeram deixar o episcopado numa data estipulada e abraçar a vida monástica. (DAMIANO, 1844, p. 986-987).

No capítulo 35, Damiano apresenta a sua primeira descrição da simonia e o costume por parte do próprio clero de não vê-la como uma falta, tolerando-a. Entretanto, o elemento mais marcante nessa primeira referência reside na forma como ele soluciona o problema, propondo a regulação da vida episcopal e sacerdotal a partir da experimentação dos preceitos monásticos de obediência e vivência comunitárias. Segundo Damiano, a prática simoníaca estava vinculada ao hábito dos clérigos viverem como se fossem laicos, ignorando a essência apostólica que os diferenciava e, consequentemente, corrompendo esse estado. A normalização da conduta clerical desponta como um meio efetivo de inibir a corrupção dos sacerdotes e bispos, coibindo a proliferação da simonia. O caminho anunciado como mais eficiente para essa ação normativa foi justamente a valorização 
dos preceitos fundantes da prática monástica beneditina, quais sejam, a obediência ao superior e a experiência de vida em comunidade.

Estaria estabelecido um processo de valorização do monasticismo, a ponto do mesmo não apenas influenciar, mas orientar a experiência disciplinar episcopal e sacerdotal? Verificamos uma tendência no primeiro texto hagiográfico de Fonte Avellana que se confirmou nas epístolas redigidas durante o priorado de Pedro Damiano (1043-1057): a construção de uma argumentação de luta contra a corrupção sacerdotal pautada pela defesa de que o sacerdote precisa passar pelo disciplinamento monástico para se eximir de experiências que o conduziram à corrupção do estado clerical. Esse processo que outros historiadores chamaram de monastização ou "monaquização" do episcopado (PINHEIRO, 2010, p. 4; FIGUINHA, 2009), baseava-se no estabelecimento de uma rígida disciplina para o clero secular, fundada na experiência regular cenobítica. Para fundamentar sua argumentação de luta contra a simonia, Damiano enfatisou essa experiência regular como um caminho para recuperação sacerdotal, indo além, ao pontuar a extrema ascese eremítica, com momentos de isolamento e flagelação voluntária, como formas de sustentar o compromisso monástico.

A luta contra a simonia surge como uma bandeira a ser levantada pelos eremitas em franco processo de institucionalização, especialmente aqueles que se diziam vinculados à tradição perpetuada pela memória de São Romualdo. Nessa específica mistura de elementos vindos do cenobitismo e do anacoretismo, definitivos para a correção monástica e sacerdotal, o combate à simonia despontou como um componente narrativo importante, uma vez que a partir dele se definiu um inimigo a ser repugnado, ao mesmo tempo se reconheceu a legitimidade da identidade eremítica no resgate disciplinar de todo clero.

Esta proposta foi repetidamente reiterada na obra de Pedro Damiano. Em seu epistolário, a primeira menção à simonia foi feita cerca de uma ano após a redação da Vida de São Romualdo. Na terceira carta, escrita em 1043 e endereçada a Gebeardo, arcebispo de Ravenna, (1027-1044), Damiano defende que:

O dragão da simonia depois de agrupar as armas de mui- 
tos negociantes desgraçados, contornou-os com a concuspicência e vomitou seu veneno adiante. Tu fostes a única excessão, pois permaneceu invicto e ileso como cavaleiro de Cristo, penetrando a garganta da besta do inferno com a lança de Pedro e mantendo sua igreja livre deste contágio imundo. O que a sé mestre perde com as faltas de seus pastores, ou melhor, de seus ladrões, a sé deste nobre discípulo preserva inviolada. [...] Eis que surge o cavaleiro de Cristo que bravamente reúne sua força e com prudente circunspecção luta contra os vícios do diabo. Degolas a avareza, esmagas o orgulho, ergues os caídos, estendas aos fracos a mão direita do santo conselho, enquanto guardas tua própria integridade atrás do escudo das santas virtudes, ao mesmo tempo, tu podes defender os outros contra o ataque do antigo inimigo. (DAMIANO, 1983, p. 107).

A simonia surge caracterizada como um dragão venenoso que contaminou os clérigos com a avareza e o orgulho, origem de todos os males engendrados pelo diabo. A partir dessa passagem, Damiano estabelece todo um corpo de adjetivos que caracterizarão tanto os praticantes quanto a prática da simonia. Os praticantes são chamados de negociantes desgraçados (miserabilium negociatorum) e ladrões (latronum) que, além de disporem ilicitamente dos bens sagrados, enroscam-se à concupiscência (concupiscentiae spiris). Já aquele que se coloca como combatente dessa falta, é designado como cavaleiro de Cristo (Miles Christi), que dispunha do escudo das santas virtudes para se tornar invencível (omnibus invictus) diante desse mal contagioso. Mas, para além do arsenal de qualificativos trazido por Pedro Damiano para fundamentar o combate à simonia, dois elementos dessa epístola são importantes para nossa análise: o primeiro diz respeito à constatação do estado de corrupção presente na Sé Romana (magistri sedes), enquanto Ravenna preservava-se da contaminação da simonia; o segundo trata do compromisso público do arcebispo em auxiliar àqueles homens fracos que sucumbiam ao dragão da simonia.

No início de sua atividade enquanto prior, Damiano denunciou o jogo de interesses presentes na Sé Romana, identificando-na como um espaço contaminado pelas práticas simoníacas (BOVO, 
2011). Apesar de não condenar explicitamente o papa Bento IX por simonia, ele anunciou a condição da Sé Apostólica que perdeu sua pureza por culpa de certos "pastores ladrões". Numa referência clara ao prestígio apostólico de Ravenna, historicamente reconhecida como local da ordem cristã, o avelanita reafirmou o lugar dessa Sé como uma "segunda Roma"4. Segundo Alba Orselli, a triangulação eclesiológica entre as principais sedes do cristianismo, sua igualdade em termos de autoridade doutrinal e seu peso político encontram-se referenciados nessa passagem epistolar de Damiano (ORSELLI, 2009 , p. 145-146). Afirmar a condição ilibada de Ravenna em detrimento de Roma poderia servir a um objetivo: autorizar a linhagem sacerdotal ravenate da qual o próprio Damiano fazia parte, uma vez que era sobrinho do arquidiácono de Ravenna, Damiani, e foi consagrado pelo arcebispo Gebeardo ${ }^{5}$. Temos aqui o reconhecimento do prestígio apostólico da igreja de Ravenna e, consequentemente, a sustentação da aptidão de seu clero em fomentar o combate à simonia, inclusive intervindo em Roma, caso fosse preciso.

Ao verificarmos as cartas seguintes do epistolário Damianense, constatamos que essa condição considerada impoluta e protetora do arcebispo de Ravenna não persistiu no substituto de Gebeardo, Widger (1044-1046). Tanto na carta sete, enviada a esse arcebispo, em 1044, quanto na carta vinte, endereçada ao imperador Henrique III, Damiano queixou-se do arcebispo ravenate, declarando o descaso dele em reconhecer sua contribuição nos assuntos doutrinais. Vejamos:

É ocasião de dizer: Glória a Deus nos céus e paz na terra aos homens de boa vontade. Venerável pai, eu estou surpreso que depois de minha visita, depois de me apresentar obediente diante de teu convite, eu não tenha ouvido mais nada de tua missão, nem recebido uma simples indicação de tua amizade. Certamente existem diversas testemunhas do que falo, ou seja, que se eu estivesse disposto a agir de acordo com a memória abençoada de seu predecessor e adquirido residência aqui, ele cofirmaria, como prometeu, aceitar meu conselho sobre o bem de sua própria alma e também sobre os regulamentos das questões espirituais. 
Mas tu, ao contrário, diariamente flagela-me, a cada dia me impõe amargos golpes; e quem não merece ouvir uma palavra dura, recebe a disciplina de tuas mãos sagradas. (DAMIANO, 1983, p. 116).

O avelanita reclama por Widger não dispensar a ele a mesma amizade e o mesmo reconhecimento dados no passado por seu predecessor. Cabe aqui destacar que ao se guardar na memória do bom relacionamento com Gebeardo, a quem destinava aconselhamento espiritual em troca de proteção e benevolência, Damiano declara sua expectativa sobre o arcebispado de Widger: promover a proteção dos mosteiros contra aqueles que os ameaçam e os saqueiam.

Eis aqui, clemente Senhor, que todos os outros mosteiros sob as asas de sua misericórida permanecem ilesos a servir a Deus com segurança e imunidade. Enquanto esta casa sozinha, a partir do momento que tu me mandaste assumir a sua posse, sofreu muitos ataques e depredações, se tu não demonstrar ao menos uma inclinação à misericórdia, ela estará condenada à completa desolação. Assim, do meu ponto de vista, parece que a casa de Deus tem sido arruinada por aquele de quem, pela ajuda de Deus, era esperado ser elevado ao mais alto céu. Portanto, glorioso senhor, com lágrimas nos olhos eu caio aos teus pés e imploro à tua santa natureza piedosa que considere retirar seu chicote e limitar sua excessiva perseguição, como o Senhor disse pelo profeta: 'em vossa ira, lembrai-vos da misericórida'. Nunca oprima um santo lugar retirando seu dinheiro, este que, como tu bem sabes, já perdeu tantos bens eclesiástico (DAMIANO, 1983, p. 116-117).

Expectativa essa que Widger não atendia, justamente por oprimir monetariamente o mosteiro de São Apolinário em Classe, casa cenobítica colocada aos cuidados da Ermida de Fonte Avellana pelo próprio arcebispo ravenate. Aqui Widger foi aconselhado a retomar o que Damiano considerava ser o papel primordial do arcebispo ra- 
venate: garantir às imunidades e isenções monásticas submetidas ao seu domínio. Mas, enquanto o arcebispo assegurava a imunidade de outras casas, desrespeitava o mosteiro de Classe, usufruindo de suas posses. Essa carta torna-se muito significativa, pois através dela podemos identificar a estreita relação entre a prática de dispor do ofício sagrado em troca de dinheiro, favores ou presentes, bem como as expropriações sofridas e denunciadas por inúmeros mosteiros.

Numa clara menção à condição de corrupção que circundava o arcebispado de Ravenna, sob o comando de Widger, Damiano acusa-o abertamente, em 1046, na carta endereçada ao imperador Henrique III:

[...] em pessoa, o rei derrubou a cadeira de Widger aquele comerciante da Igreja. [...] Mesmo assim, não quero ignorar meu Senhor Rei que este homem pernicioso transmitiu suas cartas pretensiosas para Ravenna; algumas, na verdade, enviadas secretamente para indivíduos e outras dirigidas à toda a Igreja, em que ele se comprometeu a fazer tudo o que desejassem sobre os bens da Igreja. Se eles fossem contrários a acreditar em suas palavras, ele instruiu seu mensageiro a jurar que suas palavras eram verdadeiras. Por conseguinte, não tenho dúvidas que certos cidadãos de Ravenna irão sugerir a vossa majestade que ele possa retornar à sua antiga Sé. Obviamente, saqueadores do mundo, que procuram roubar os bens da Igreja, desejam um tipo de bispo que não fique no caminho de sua pilhagem. (DAMIANO, 1983, p. 201-202)

O avelanita reconheceu Widger como um dissimulado que ajudava a destruir a "casa de Deus" (domus Deı). Nesta epístola, Damiano define abertamente Widger como um simoníaco que comercializava bens espirituais. Novamente encontramos relacionada à prática da simonia a expropriação dos bens eclesiásticos: como um comerciante da Igreja (ecclesia negotiantis), Widger buscava apoio da aristocracia local e também dos eclesiásticos de Ravenna, servindo-se justamente dos interesses desses últimos em controlar ou usufruir dos bens eclesiásticos (robus ecclesia), para resguardar seu retorno ao arcebispado daquela cidade. Ao anunciar como um bispo não 
deveria se portar diante dos bens, imunidades e isenções colocados sob sua salvaguarda, Damiano deixou transparecer o receio de ver um bispo como Widger restituído em suas funções. Isto porque o avelanita não ignorava a possibilidade de um arranjo dessa natureza.

Essas duas cartas foram as primeiras a divulgar, para além da circulação classence da Vida de São Romualdo, a principal bandeira do eremitismo avelanita: a denúncia daqueles altos dignitários eclesiásticos que abusavam dos mosteiros, visando ao benefício próprio. Apesar de Damiano alterar o tom do texto enviado diretamente a Widger daquele endereçado ao imperador Henrique III, o que fica dessas duas epístolas é a declaração do descontentamento monástico com a condução episcopal. Damiano é o porta-voz desse descontentamento, ao mesmo tempo em que se anuncia como o portador dos "regulamentos das questões espirituais" (spiritalium rerum ordinacionibus), capaz de reconduzir o arcebispo à boa condução da vida monástico-sacerdotal. O bom conselho vinha das lideranças espirituais dos ambientes ascéticos. Mas esta posição não era perpétua. Estas epístolas apresentam outra atribuição importante da liderança eremítica: a contínua necessidade de se apelar à memória para reiterar o peso da autoridade ascética sobre os assuntos eclesiásticos, mesmo ela tendo sido reconhecida pelas lideranças anteriores da Sé ravenate.

Um dos principais textos de Pedro Damiano a tratar da simonia foi composto pouco depois dessas denúncias, em 1052. Na carta conhecida pelo nome de Liber qui appelatur Gratissimus, ele desenvolveu uma densa reflexão a respeito das práticas simoníacas (DAMIANO, 1983, p. 384-509). Endereçada a outro sucessor do arcebispado Ravenate, Henrique (1051-1072), Damiano discutiu a validade dos sacramentos ministrados por bispos simoníacos, contribuindo para o debate estabelecido pelos sínodos quaresmais convocados pelo papa Leão IX entre 1049 e 10516. Se nesses sínodos e concílios pretendeu-se caracterizar o comportamento simoníaco, suas consequências para a validade das ordenações sacerdotais e as punições cabíveis a partir de um parâmetro comum, o Liber Gratissimus materializou a existência de diversas interpretações sobre a questão entre os próprios representantes do círculo papal e a impossibilidade de reuní-las sob um mesmo entendimento. 
No início do Liber Gratissimus, Damiano anuncia a estreita relação entre os sínodos romanos e sua disposição de tratar do tema da simonia, bem como adverte o arcebispo de Ravenna sobre o debate articulado que dividiu a opinião dos aliados pontifícios:

Tu, por obra de Deus, acabaste de receber a consagração; assim acreditei ser mais conveniente te oferecer como presente o que eu tenho escrito sobre o sacerdócio. Acredito que não desconheças os debates nos três concílios romanos dos últimos três anos sobre aqueles que foram consagrados, mesmo que gratuitamente, por simoníacos e quanta perplexidade, confusão e incerteza se difundiu hoje em dia a esse respeito; especialmente porque, com o crescimento da agitação e da dúvida chegou-se ao ponto de alguns bispos, como se vê, novamente consagrarem clérigos que foram ordenados por simoníacos. Um grande número de irmãos, com insistência e a expectativa crescente de caridade, fraternalmente chamam-me e, por assim dizer, constrangem-me com fortes súplicas para não escapar a tarefa de vir ao seu auxílio para atender a necessidade de saber como são as coisas, pelo menos escrevendo algo breve que manifeste minha opinião sobre essa questão. Por algum tempo, recusei-me a fazê-lo, na esperança de receber as primeiras orientações do abençoado sumo sacerdote da Sé Apostólica; Dizia-se que em breve iria passar essas orientações. Deste modo, me propus a tratar inteiramente da questão, se a autoridade do Príncipe da Igreja fosse favorável a mim, a despeito de qualquer assunto eclesiástico. Lembro-me que já no último sínodo o venerável papa, depois de ter suplicado ao Senhor, rezou fervorosamente a pedir a todos os bispos, a misericórdia de Deus para que revelasse aos duvidosos o que deveriam decidir sobre tão difícil questão e assim me mantive obediente ao seu comando, se com a luz da graça divina conseguisse desmantelar, pela oração e pela escrita, um nó tão firme da Igreja (DAMIANO, 1983, p. 390-393).

Recorrendo à exegese bíblica, à interpretação dos Santos Padres, à História do Cristianismo, especialmente ao direito canônico, 
Pedro Damiano fundamentou a doutrina da validade dos sacramentos ministrados por bispos simoníacos. Se, à primeira vista, essa defesa pareceria contraditória, uma vez que o prior de Fonte Avellana se demonstrava um ardoroso combatente dos bispos simoníacos de sua região, ela não desvirtuava ou mesmo enfranquecia a luta inicial deste avelanita contra a simonia. Pelo contrário, a defesa da validade dos sacramentos ministrados por simoníacos colocava Pedro Damiano no centro dos debates conciliares, projetando-o como o responsável pela fundamentação doutrinal contrária à tradição de considerar corrompido os sacramentos dispensados por maus sacerdotes. Tradição essa que remontava à querela donatista e a posição defentida por Agostinho (LEYSER, 2000), cuja adoção entre os partidários pontifícios da segunda metade do século XI encontrou seu maior representante no cardeal Humberto de Silva Cândida.

Em seu Adversus Simoniacos, composto por volta do ano 1057 e em resposta ao Liber Gratissimus, Humberto negava a validade dos sacramentos dispensados por sacerdotes que, desde a ordenação, fossem reconhecidamente simoníacos; além deles, o cardeal Silva Cândida também invalidava os sacramentos ministrados por sacerdotes consagrados gratuitamente, se eles tivessem recebido os ofícios das mãos de bispos corruptos. Para Humberto, da mesma maneira que Simão Mago, os simoníacos cometeram heresia por terem pago para serem consagrados. Portanto, suas ordenações nunca foram legitimamente efetivadas. Eles não receberam a graça do Espírito Santo. Como ninguém poderia dar aquilo que não recebeu, os ofícios posteriormente dispensados por eles não tinham valor sacramental. Segundo essa interpretação, o mérito pessoal do encarregado de manipular o sacramento determinava sua força e sua validade (SILVA CÂNDIDA, 1980, p. 95-253).

Diferentemente, Pedro Damiano defendeu em seu Liber Gratissimus que os sacramentos ministrados por simoníacos eram válidos, uma vez que o verdadeiro autor do sacramento não era o sacerdote, mas Deus.

Se alguém pode argumentar para mim que o batismo da regeneração humana é uma coisa e a consagração na dig- 
nidade eclesiástica é outra, nós responderemos que todos os aspectos considerados válidos para o batismo também o são para a consagração. Sendo o batismo a origem e o princípio da ação sacramental na Igreja, de tal modo que essa ação pertence a Deus e não ao homem, da mesma maneira a consagração eclesiástica compete Àquele do qual flui a plenitude de todas as bençãos. (DAMIANO, 1983, p. 397).

O avelanita referencia-se na autoridade da interpretação nicena do batismo para reguardar à consagração episcopal o mesmo caráter doutrinal. De forma mimética, a consagração nas dignidades eclesiásticas respondia aos mesmos elementos sacramentais do batismo. Se, pelo batismo, o homem renascia para uma nova e verdadeira vida, através da ordenação sacerdotal/episcopal, agora, era o cristão que renascia para uma nova vida, na qual a castidade, a humildade e a pregação conformavam-no ao modelo apostólico, destacando-o como liderança responsável na condução dos cristãos à salvação. Sendo Deus quem concede a graça por meio do batismo, também é Ele que confere o Espírito Santo aos ordenados.

Supondo então que, tanto num quanto no outro, a sua essência e magnificência se constituem no fato do Espírito Santo ser recebido tanto por aqueles que são batizados, quanto por aqueles que são consagrados. Como o batismo não está atribuído a virtude humana, mas à autoridade divina, por isso é necessário que qualquer consagração eclesiástica seja totalmente referida à Deus: em todos os casos trabalha a multiforme graça de Deus, para que alguns obtenham a absolvição dos pecados e outros sejam promovidos nas ordens das várias dignidades espirituais; para que aquele, despojado do velho homem com sua conduta errada, se descubra um homem novo, e aquele, como sacerdote de Deus, se cubra de justiça; a fim de que este, como uma criança recém nascida, mas dotada de Espírito, querendo sem engano o leite, atinja a medida da plenitude da idade de Cristo. O Espírito age neles porque tornaram-se filhos por adoção, e nos outros porque são ministros e dispensadores dos mistérios de Deus. Os 
primeiros mediante o Espírito renascem, os segundos pela diposição do mesmo Espírito foram eleitos porque geram os filhos de Deus (DAMIANO, 1983, p. 397-398).

O mérito pessoal dos membros da hierarquia eclesiástica não influenciava a capacidade de transmissão da graça divina. O sacerdote era apenas um ministro, um instrumento para o verdadeiro autor do sacramento. Preocupado em exemplificar como uma consagração fornecida por bispos simoníacos não corrompia a obra milagrosa de muitos sacerdotes, monges e eremitas, Damiano defende a ideia de que não havia uma predisposição íntima à corrupção entre os clérigos consagrados por simoníacos, visto que a obra santa deles demonstrava sua "[...] própria piedade e honestidade; e a culpa daqueles que conferiram a ordem não arruinava a pureza e a inocência do ordenado" (DAMIANO, 1983, p. 478-479). Ele recorreu ao próprio exemplo, bem como aos casos análogos de seus contemporâneos, os Beatos Romualdo de Camerino, Amico de Rambone, Guido de Pomposa e Firmano de Fermo, para defender a ideia de que não há uma predisposição à corrupção daqueles clérigos consagrados por simoníacos. Dessa maneira, ao dar uma nova solução para o problema da ordenação simoníaca, o avelanita deixou aberta a possibilidade de correção da falta.

Apesar de minimizar as consequências da consagração simoníaca, a posição teórica de Damiano não eliminava a gravidade atribuída a essa falta. Pelo contrário, o prior de Fonte Avellana utilizou a recordação de inúmeras passagens da história do cristianismo para definir a simonia como um problema disciplinar da Igreja e não apenas uma altercação doutrinal. Em vista disso, a correção dessa falta poderia ser trabalhada pelas lideranças clericais, especialmente junto àqueles recém-consagrados sacerdotes que desconheciam as ações corruptas de seus consagradores.

Com o vigor da autoridade expressa no sínodo [Roma], ele [papa Leão IX] anulou todas as ordenações simoníacas; rapidamente um grande número de sacerdotes de Roma se levantaram numa grande manifestação de protesto afirmando, não apenas eles, mas também uma grande parte 
dos bispos, que quase toda basílica foi privada dos ofícios sacerdotais e, sobretudo, tiveram que renunciar a todas as celebrações da Missa, provocando a ruína da religião cristã e o desespero de todos os fiéis que viviam em torno deles (DAMIANO, 1983, p. 498-499).

Segundo Damiano, as deliberações condenatórios do sínodo Romano de 1049, no qual o papa Leão IX anulou toda as ordenações simoníacas, materializou os problemas práticos advindos desse tipo de posição extrema: de um lado, o risco da privação dos ofícios sacerdotais, especialmente da celebração da missa; de outro, a dificuldade em administrar o desespero da multidão de fiéis sem acesso aos serviços espirituais. Não foi por acaso que, diante da manifestação dos sacerdotes e bispos romanos, o pontífice tenha voltado atrás na decisão, determinando àqueles que tivessem sido destituídos dos seus ofícios e tivessem recebido consagrações sacerdotais gratuitas, o emprego de uma "[...] penitência de quarenta dias para que pudessem voltar a prestar o serviço no ofício recebido" (DAMIANO, 1983, p. 499).

Para Damiano, a melhor maneira de combater a venalidade presente na prática simoníaca estava na valorização dos preceitos ascéticos, tanto nos fundamentos cenobíticos - como a prática da obediência ao superior e a experiência de vida em comunidade quanto nos anacoréticos - como a contemplação solitária e a prática da autodisciplina. O enrigecimento da disciplina clerical poderia resguardar o combate à hidra da corrupção eclesiástica.

Portanto, peço-lhe caríssimo pai, pelo todo poderoso Jesus, por seus anjos, pelo trono ardente de sua majestade de onde irá julgar os vivos e os mortos, não se engane, não demore mais tempo, nem jogue fora o remédio para a salvação de sua alma diariamente corrupta, mas encaixe-se rapidamente, enquanto ainda podes, no refúgio da conversão, para que o desastre repentino não te atinjas enquanto esperas, para que as ondas da morte inesperada não te envolvam e tu sejas engolido pelo inferno. Oh, meu pai, por 
que sou incapaz de conseguir que Deus lhe dê a introspecção e permita que estejas ciente da cama de calamidades na qual descuidadamente descansas? Certamente, se fosse visível para ti que a morte está por perto, deitada atrás de ti à tua espera, tu imediatamente abandonarias tudo o que foi agradável neste mundo, tudo o que nessa vida enganosamente te seduziu (DAMIANO, 1983, p. 283).

$\mathrm{Na}$ epístola trinta, de abril de 1049, Damiano advertiu o bispo Gislério de Ósimo da sua condição corrupta, indicando como opção para sua recuperação "a entrada num refúgio de conversão". Numa evidente tentativa de empreender a correção episcopal, o avelanita utilizou a metáfora do "refúgio" para definir o espaço propício para a correção clerical. Esse refúgio pode ser identificado com a cella eremítica, cuja fundamentação teológica se encontra desenvolvida na vigésima oitava carta, escrita em 1048, pouco antes do envio desta última. Segundo Damiano, a cella eremítica era "[...] a oficina maravilhosa do esforço espiritual, em que certamente a alma humana restaura dentro de si a imagem de seu criador e recupera sua pureza original" (DAMIANO, 1983, p. 273). Utilizando-se dessa fundamentação, o avelanita recuperou uma de suas principais referências disciplinares para anunciar ao referido bispo a possibilidade de correção das suas faltas, indicando a ele que o estado calamitoso no qual se encontrava era fruto das seduções mundanas. $\mathrm{O}$ "refúgio da conversão" surge assim como um espaço purificador, onde, através da contínua introspecção, recuperava-se a consciência do erro, corrigindo-o. Uma correção que, ao ser engendrada pelo próprio exercício disciplinar de reflexão e contemplação solitárias, permitia ao faltoso a vivência interior capaz de promover a consciência de suas próprias faltas. Desse modo, Damiano confirmou, através de suas ações e de seus conselhos, a proximidade com o modelo de conduta eremítico professado desde a Vida de São Romualdo, especialmente por encarnar na sua própria trajetória à frente do priorado de Fonte Avellana o exemplo da intervenção contra a simonia.

Dessa maneira, a simonia é classificada na obra de Damiano como um mal contagioso, engendrado pelo diabo, que envolve o cultivo da avareza, da concupiscência, da soberba e do orgulho. 
$\mathrm{O}$ vocabulário aplicado à prática da simonia remonta ao estímulo diabólico, com a identificação dos vícios mais nefastos e do seu principal símbolo: a hidra. A representação metafórica da hidra de várias cabeças, cuja imortalidade e capacidade de regeneração atualizava entre os medievais os efeitos da corrupção íntima fomentada pelos vícios mundanos (FRASSETTTO, 1998). Entretanto, apesar do estado corrompido dos bispos simoníacos, existiam maneiras de restituir-lhes uma condição original impoluta.

O disciplinamento ascético era um entre tantos caminhos que permitiriam a eles trabalhar por sua própria salvação. Mas vale ressaltar que o combate à simonia servia a determinados interesses. Se durante o priorado de Damiano, a intenção de valer-se da luta contra a simonia atendia às prerrogativas de afirmação institucional da comunidade eremítica avelanita, em seu cardinalato (1057-1066), outras prerrogativas também deveriam ser atendidas. Eram instáveis os terrenos da condenação simoníaca: a acusação, a defesa ou o castigo dependiam das circunstâncias dadas. A própria separação entre o mérito pessoal dos sacerdotes e a validade de suas obras ministeriais, presente na teoria do Liber Gratissimus, permitiu àqueles que lutavam contra a simonia conduzirem o sentenciamento considerando as conjunturas, os homens envolvidos e sua importância na sustentação da primazia romana em arbitrar o disciplinamento clerical. Em outras palavras, a acusação de simonia era um instrumento de poder que dinamizava as relações sociais, permitindo a determinados grupos eclesiásticos construírem sua supremacia sobre outros.

Vejamos a descrição do final do juramento de Guido de Velate, arcebispo de Milão (1045-1067), feita por Damiano na carta enviada a Hildebrando de Soana, em 1059, durante a tentativa de resolução do conflito entre os patarinos e o clero milanês.

Para a recepção dos graus eclesiásticos, seja por mim ou pela pessoa do submisso ou por qualquer outro meio, eu não dei ou prometi qualquer coisa, nem prometeram me dar no futuro qualquer coisa. Então Deus e os Santos Evangelhos me ajudem. Após fazer isto, o senhor arcebispo com toda humildade, em seguida, ajoelhou-se no chão e pediu que uma 
penitência fosse imposta a ele pela venalidade e pelo abominável comércio cometidos; e embora ele não fosse o criador deste crime na sua igreja, ele não tinha extirpado, como era seu dever. E assim lhe impus a penitência de cem anos, que poderia ser resgatada com o pagamento anual de uma quantia em dinheiro (DAMIANO, 1988, p. 243-244).

Pedro Damiano, enquanto legado papal e representante apostólico, correu o risco de ter sua sentença incorporada à lista do comércio simoníaco, uma vez que propôs a troca de uma penitência por dinheiro. A troca de um bem espiritual, tido aqui como uma sagrada correção capaz de redimir o erro, por algo venal, por algo que partilhava do mesmo princípio corruptível da ação simoníaca. Em um contexto em que a prática da simonia era repetidamente condenada nos concílios, transformando-se no principal tema de debate entre as lideranças eclesiais, como explicar que a autoridade apostólica incumbida de julgar uma acusação de simonia recorresse à venalidade de um pagamento para expurgar o peso deste grave pecado? A norma não era uma referência autofuncional, dotada de caracteres autorreferenciais, que enrigeciam um dever ser, impondo-o sobre as relações sociais. No primeiro plano desse processo, estavam os agentes, ou melhor, a "personna" por traz da interpretação da falta e do pronunciamento do castigo (RUST, 2010, p. 101-105).

Dessa maneira, Pedro Damiano, como cardeal-bispo de Óstia, poderia adaptar uma penitência que pudesse ser efetivamente cumprida pelo sentenciado e não o impedisse de permanecer à frente do arcebispado de Milão. Não sejamos iludidos pela capa de austeridade ascética sustentada por nosso agente histórico durante seu priorado em Fonte Avellana. Em 1059, em sua primeira missão enquanto legado papal, Damiano não poderia sobrepujar os vínculos anteriormente estabelecidos com a igreja de Milão, especialmente com Guido de Velate, seu maior aliado no apaziguamento dos patarinos e na afirmação da primazia romana sobre a igreja milanesa (VIOLAN'TE, 1955).

O laço de amizade com Guido pode ser comprovado através da carta cento e um, escrita em 1063, na qual Damiano o compara ao "anjo do Senhor", promotor da vontade divina: 
[...] mas como recordo da maneira que me destes este presente, lembro da indicação de Zacarias: 'Josué, vestido com roupas sujas, estava de pé diante do anjo do Senhor'. O Senhor falou àqueles que estavam à volta dele: 'tirai-lhes essas roupas sujas'. Assim, como continua a Escritura, eles colocaram roupas limpas sobre ele. [...] É suficiente que eu diga, que tu, venerável pai, te transformastes no meu anjo do Senhor e, por amor a Jesus, removeste minha roupa suja, adornandome com vestuário sacerdotal (DAMIANO, 1989, p. 117).

Pretendendo dar uma aparência sacralizada aos presentes que recebeu da mão do próprio Guido (novas vestimentas), visto que a recepção de presentes naquele momento também poderia ser interpretada como uma tentativa de agradar o responsável por presidir a cerimônia de condenação ou absolvição do clero milanês, Damiano utiliza metáforas bíblicas para justificar a intenção do arcebispo. Temos aqui um exemplo importante de como alguns artifícios retóricos podem ser empregados para positivar certas ações episcopais, que em sua essência poderiam ser enquadradas como prática da simonia.

Durante as cartas de seu cardinalato, o reconhecimento da simonia e sua condenação da simonia adquiriu novas possibilidades. Agora, a acusação, a defesa ou o castigo dessa falta dependiam antes da legitimidade daqueles que a professavam. Pedro Damiano sustentou um arcebispo acusado de simonia entre seu povo, porque naquele momento ele era uma figura importante na defesa da supremacia da Sé Apostólica, um defensor da hierarquia eclesiástica sustentado pelo grupo pontifical de Hildebrando de Soana, Humberto Silva Cândida, Anselmo de Lucas e do próprio Pedro Damiano. Se aos nossos olhos tal atitude parece arbitrária, para Damiano tratava-se de manter um vínculo importante, num contexto em que os agentes papais dependiam dessas amizades para sustentar sua correlação de forças sobre Roma e a primazia da primeira Igreja de Cristo.

Conservar a flexibilidade do exercício jurídico era uma condição para sustentar a representação papal enquanto instância de poder decisório. Para isso era preciso se adaptar às tensões, aos conflitos e, principalmente, descentralizar sua política eclesiástica. O combate à simonia foi um dos instrumentos que serviram para mi- 
nar e desacreditar condições ofensivas para esse grupo heterogêneo de eclesiásticos encerrados no círculo papal, além de permitir-lhes legitimidade para identificar seus oponentes e defender seus aliados.

Outra referência dessa maleabilidade no julgamento da simonia na correspondência de Pedro Damiano está na carta cento e quarenta e seis, escrita em 1067 e destinada ao povo de Florença. Nela Damiano faz pesada acusação a um grupo de monges da cidade que conduzem uma campanha de difamação contra o bispo Pedro Mezzabarba (1062-1068), acusando-o de simonia. Para defender a validade dos sacramentos ministrados pelo referido bispo, Damiano desautoriza esse grupo monástico, acusando-os de se valerem de uma "santidade odiosa" para insuflarem o povo contra seu bispo.

Santidade é odiosa se cai em heresia e se negar a seguir o caminho tradicional, é forçada a vagar por estradas sinuosas e perigosas armadilhas. [...] Se como homens que vivem nos mosteiros estamos destinados a ser caçadores de Deus, como disse Isaías: enviarei meus caçadores e eles devem caçar, depois de abandonar os bens deste mundo, devemos mostrar nossos dentes, rosnar para o outro e rasgá-lo com nossas garras como se fossemos cães raivosos? Reprima-se agora a insuflada presunção que coincide com a odiosa santidade dos irmãos. Aquele que quer ser santo perante Deus, deve preferir a doença do irmão à arrogância. Quem deseja ser santo, deve estar diante dos olhos de Deus e não se orgulhar de ser melhor que o irmão mais fraco. Um cão jovem, cujo dever é afastar os estranhos, nunca deve negligenciar sua responsabilidade e começar a atacar os membros da família, senão ao invés de dormir tranquilamente na casa, ele será forçado a ficar ao relento (DAMIANO, 1989, p. 541-542).

Criticando severamente o modo de vida desses monges, Damiano condena-os pela soberba de se considerarem mais santos do que outros eclesiásticos. Ao reconhecê-los como jovens religiosos, Pedro alerta-os a cumprirem seu papel de guardar a casa de Deus, aconselhando-os a não se preocuparem com as atribuições alheias, concentrando-se apenas em cumprir bem suas próprias funções. $\mathrm{O}$ 
avelanita não mede esforços para desqualificar a acusação desses monges que se envolvem em assunto que não lhes dizem respeito, mesmo reconhecendo que o bispo Mezzabarba devia explicações ao papa. Comparando-os a gafanhotos, o recém-afastado cardeal-bispo desaprova abertamente a atitude dos monges ao se envolverem em assuntos da política eclesiástica, quando deveriam estar comprometidos com sua vocação de lamentar pelos pecados dos homens, orando por eles e não os condenando.

Seria essa mais uma incongruência das formulações de Pedro Damiano, visto que durante todo seu priorado e seu cardinalato se colocou como um defensor da purificação eclesiástica? Não nos parece isso. A relutância em aceitar e validar a denúncia desses monges estava muito mais próxima da defesa de outro princípio canônico: de que o julgamento de um bispo exigiria uma assembleia conciliar ou uma ação dos representantes pontifícios, e não uma campanha difamatória irregular (CUSHING, 2005, p. 741).

Os monges acusados dessa falta de humildade eram os valombrosanos. Segundo Kathleen Cushing, por volta de 1050, os valombrosanos passaram a ser valorizados por sua rigorosa observância monástica, sendo vistos pelos papas do período como um centro propício à promoção ativa da renovação cristã. Mesmo aproximando-se dos avelanitas, no que diz respeito ao ideal de extrema ascese, os valombrosanos divergiam fortemente no tipo de ação e estratégias empreendidas para combater a simonia e a corrupção episcopal. Partidários da interpretação simoníaca proposta por Humberto de Silva Cândida, eles acreditavam que os simoníacos contaminavam com sua centelha corrupta todos aqueles que recebiam seus sacramentos; Por isso, o ataque ao bispo Mezzabarba. Os valombrosanos aparentemente não só incitaram os florentinos a rejeitarem Mezzabarba, mas também todos os sacerdotes ordenados por ele, afirmando que os sacramentos de tais sacerdotes eram inválidos (CUSHING, 2005, p. 747).

Nesse momento, defender a validade da ordenação simoníaca significava para Damiano afirmar a legitimidade de sua perspectiva teológica e, sobretudo, resguardar o espaço de ação política conquistado por Fonte Avellana durante seu cardinalato. Ao desautorizar os valombrosanos, ele autorizava a si mesmo e aos irmãos 
avelanitas a agir em nome do papado, mesmo após ter deixado por vontade própria o episcopado de Óstia. Essa intenção de Damiano nos conduz a uma constatação: mesmo entre os colaboradores papais, não havia unanimidade sobre as ações de combate à simonia, menos ainda um programa ou agenda comum estabelecida para a formalização de uma "reforma gregoriana".

\section{Considerações finais}

A partir da caracterização instável da simonia presente na correspondência de Pedro Damiano, podemos afirmar ser este um recurso utilizado por diferentes grupos eclesiásticos com objetivo de afirmarem seu poder e resguardarem seus espaços de intervenção junto ao papado, aos ambientes senhoriais do regnum italicum e à corte imperial germânica.

Os resultados encontrados em sua correspondência permitem-nos recolocar o tema da reforma gregoriana dentro da complexidade ideológica e social da qual ele faz parte. Permanece um questionamento: é possível afirmar que entre 1040 e 1070 existiu uma noção geral de reforma fundamentando a atividade de combate à corrupção eclesiástica entre os diversos grupos monásticos e os representantes episcopais da península itálica?

Estudos monográficos como os de Maureen Miller sobre a Igreja de Verona (950-1150), John Howe sobre o patronato de Dominique de Sora (século XI), Kathleen Cushing sobre a obra canônica de Anselmo de Luca (século XI), Leandro Rust sobre as disputas de poder envolvendo o papado dos séculos XI ao XIII e, finalmente, os exemplos de maleabilidade na fundamentação doutrinal do combate à simonia atestados na correspondência de Pedro Damiano nos permitem afimar que não existe uma noção geral de reforma da Igreja no século XI, orientando ações pontifícias e de seus apoiadores. O que encontramos são sentidos diversos de regularização da vida clerical, originários de agentes e grupos eclesiásticos distintos que, às vezes, concorrem, às vezes articulam-se, fundamentando ações políticas para a expansão do poder eclesiástico no período. 


\section{THE BATTLE AGAINST SIMONY IN PETER DAMIAN'S CORRE- SPONDENCE: A REFORMER RHETORIC IN ELEVENTH CEN- TURY?}

Abstract: The simony has a long history of qualification and combat in Christian texts. In correspondence of Peter Damian found its main ecclesiological conceptions and the appropriate actions to combat this sin, which for many historians was the integrator element of a reform programme spearheaded by the papacy in the 11th century. From of the diachronic organization of Damian's epistolary (1042-1072), in this article we will do a review of these studies, investigating the meanings of simony's combat filed by avelanita. Specifically, we are interested in understand whether simony was a part of a "reform program" encouraged by the papacy and endorsed by partners of Peter Damian, or if it was a prerogative to strengthen and institutionalizing the eremitical community of Fonte Avellana. Keywords: Simony. Peter Damian. Gregorian Reform. Fonte Avellana.

\section{Notas}

1 "Se qualquer bispo realiza uma ordenação por dinheiro e coloca a graça invendáveis na venda e ordena por dinheiro um bispo, um bispo rural, um presbítero ou um diácono ou algum outro daqueles numerados entre o clero; ou nomeia um gerente, um assessor jurídico ou um guarda de dinheiro ou qualquer outro eclesiástico para ganho pessoal sórdido; leve aquele que tenha tentado isso e condene-o a perder sua posição pessoal; e não deixe a pessoa ordenada lucrar nada com a ordenação ou designação que comprou; mas deixe-a ser retirada da dignidade ou responsabilidade que adquiriu por dinheiro. E se alguém parece ter agido ainda como intermediário em relações tão vergonhosas e ilegais, deixe-o também, se ele for um clérigo, ser rebaixado de sua posição e se ele for um leigo ou um monge, deixe-o sofrer anátema". Ver: Conciliorum oecumenicorum decreta. Ed. G. Alberigo et al. Bologna: Edizione Dehoniane Bologna, 1996, p. 63-64. ${ }^{2}$ O sínodo de Sutri, em 1046 e os concílios de Roma, Rheims e Mainz, em 1049, são exemplos das deliberações contra a simonia conduzidas pelo papado. Neles deliberou-se que aqueles que dirigissem as Igrejas ou os monastérios sem serem ordenados por parte do clero sofreriam a pena de anátema; assim como aqueles que comprassem ou vendessem as santas ordens ou os ministérios eclesiásticos atendendo interesses próprios. Ver: MANSI, Johannes Dominicus (Ed.). Sacrorum Conciliorum Nova et Amplissima Collectio. Tomo XIX, Graz: Akademische Druck, 1961, col. 617-618; 721-722; 725-727. Disponível em: <http://gallica. bnf.fr/>. Acesso em: 20 dez. 2011. 


\section{Claudia Regina Bovo}

3 “Terminado o período concedido para ficar entre seus irmãos, pelo mesmo motivo que foi enviado à Pomposa lhe foi ordenado dirigir-se ao monastério de São Vicente [...] lá quanto maior era o número de monges, mais vasto era o patrimônio de terras e mais relaxada era a observância monástica. Pela sua obra pastoral recuperou esse cenóbio". JOÃO DE LODI. Vita B. Petri Damiani. Patrologia Latina, v. 144, Caput VI, p. 124.

${ }^{4}$ Um direito bem conhecido por Pedro Damiano, através do cânone vinte e oito do concílio de Calcedônia, o qual definiu a autoridade apostólica de Constantinopla como lugar para onde se transferiram os cidadãos romanos.

${ }^{5}$ O próprio Damiano rememora o momento de sua consagração ao sacerdócio na epístola quarenta (Liber Gratissimus), de 1052: "Para retornar a mim mesmo, o sumo pontífice Leão se mostrou complacente comigo, apesar de indigno, sobre o ofício sacerdotal que eu portava, visto que eu ignorava o comércio praticado pelo arcebispo que me consagrou, embora nesse tempo a Sé Apostólica fosse presidida por um verdadeiro banqueiro". DAMIANO, Pedro. Epistula XL. Briefe d. dt. Kaisezeit. v. 1, 1983. p. 476-477.

${ }^{6}$ Embora desde o Sínodo de Sutri, de 1046, a simonia tenha ocupado os debates nos principais concílios e sínodos dirigidos pelos sumos pontífices e por seus legados, sua condenação e a proibição da venda de ofícios sacerdotais ou qualquer sacramento não foi definitivamente regulada até os sínodos Lateranenses de 1060 e 1061. Ver: MICCOLI, Giovanni. Il problema delle ordinazioni simoniache e le sinodi Lateranensi del 1060 e del 1061. Studi Gregoriani, v. 5, Roma, p. 33-81, 1956.

\section{Referências}

BIBLIA SACRA VULGATA. Edição eletrônica, 2006. Disponível em: < http:// vulsearch.sourceforge.net/vulgate.pdf $>$. Acesso em: 10 fev. 2012.

BLUM, Owen. Saint Peter Damian: his teaching on the spiritual life. Washington, p. 114-120, 1947.

BOVO, Cláudia Regina. Entre a Sé Romana e o Império Germânico: os significados da reforma eclesiástica na correspondência de Pedro Damiano (1043-1065). Veredas da História, ano IV, n. 1, 2011, 17 p.

CONCILIORUM OECUMENICORUM DECRETA. Ed. G. Alberigo et al. Bologna: Edizione Dehoniane Bologna, 1996.

DAMIANO, Pedro. Epistulae. MGH Briefe d. dt. Kaizerseit, tomo 4. Ed. K. Reindel. 1983-1993.

Anos 90, Porto Alegre, v. 20, n. 38, p. 75-101, dez. 2013 
Vita Romualdi Abbati. PL. Ed. J. P. Migne. V. 144. Col: 0113C-0146B. Paris, 1844-1855.

COLIN, Phipps. Romuald, - model hermit: eremitial theory in Saint Peter Damian's Vita Beati Romualdi. In: SHEILS, W. J. (Ed.). Monks, hermits and the ascetic tradition. Blackwell, 1985, p. 65-77.

CUSHING, Kathleen. Papacy and law in the gregorian revolution. The canonistic work of Anselm of Lucca. Oxford: Claredon Press, 1998.

. Of Locustae and Dangerous Men: Peter Damian, the Vallomhrosans, and Eleventh-century Reform. The American Society of Church History, n. 74, p. 4 Dez. 2005.

. Reform and the papacy in the eleventh century. Spirituality and social change. Manchester: Manchester University Press, 2005.

FIGUINHA, Matheus Coutinho. Servos de Deus: monasticismo, poder e ortodoxia em Santo Agostinho. São Paulo: Annablume, 2009.

FLICHE, Augustin. La réforme grégorienne. 3 vol. Spicilegium sacrum Lovaniense. Études et documents 6, 9 e 16. 1924-1937.

FRASSET'TO, Michael (Ed.). Medieval Purity and Piety: essays on medieval clerical celibacy and religious reform. NewYork: Taylor and Francis Group, 1998.

GILCHRIST, Jonh Thomas. Simoniaca haeresis and the problem of orders from Leo IX to Gratian. In: Canon Law in the Age of Reform, 11th-12th centuries. Variorum, 1993, p. 209-235.

HOWE, John. Church reform \& social change in eleventh-century. Dominic of Sora and his patrons. Philadelphia: University of Pennsylvania Press, 1997.

LEYSER, Conrad. Authority and ascetism from Augustine to Gregory the Great. Oxford: Claredon Press, 2000.

LUCCHESI, Giovanni. Per una vita di san Pier Damiani. Componenti cronologiche e topografiche. In: San Pier Damiano nel IX centenario della morte (1072-1972). Cesena, Centro studi e ricerche sulla antica provincia ecclesiastica ravennate, 1972, v. I. p. 13-179; v. II, p. 13-160.

LYNCH, Joseph. Simoniacal entry into religious life from 1000 to 1260. Columbus: Ohio State University Press, p. 65-66, 1976.

MILLER, Maureen. The formation of a Medieval Church. Ecclesiastical change in Verona, 950-1150. London: Cornell University Press, 1993.

ORSELLI, Alba. Ravenna, città e Chiesa nell'opera damianea. In: TAGLIAFERRI, Maurizio. (Ed.) Píer Damiani: L’eremita, Il teólogo, Il riformatore (1007-2007). 


\section{Claudia Regina Bovo}

Bolonha: Centro editoriale dehoniano, 2009, p. 145-146.

PINHEIRO, Rossana Alves Baptista. Da institucionalização do monacato à 'monaquização' do episcopado na Provença de João Cassiano e dos lerinianos (séculos IV-V). Tese (Doutorado) Universidade Estadual de Campinas, 2010.

RUST, Leandro Duarte. Colunas de São Pedro: a política papal na Idade Média. São Paulo: Annablume, 2011.

SILVA CÂNDIDA, Humberto de. Adversus Simoniacos. MGH Libeli de Lite, tomo I, p. 95-253.

TABACCO, Giovanni. Privilegium amoris: aspetti della spiritualitá romualdina. In: Spiritualità e cultura nel medioevo. Napoli, 1993, p. 167-194.

VIOLANTE, Cinzio. La pataria milanesa e la riforma ecclesiastica. Roma: Istituto Storico Italiano Per il Medio Evo, 1955.

Recebido em: 07 de junho de 2013.

Aprovado em: 12 de setembro 2013. 